\title{
ENVIRONMENTAL PATTERNS IN THE ORDOVICIAN RADIATION OF ARTICULATE BRACHIOPODS: COMPARISON BETWEEN NORTH AMERICA AND THE WELSH BASIN
}

PATZKOWSKY, Mark E., Dept. of the Geophysical Sciences, University of Chicago, 5734 South Ellis Ave., Chicago, IL 60637, U.S.A.

Articulate brachiopods underwent a major taxonomic and morphologic diversification during the Ordovician, yet remarkably little is known about the environmental, ecologic, and biogeographic contexts surrounding this event. An exception is Lockley's (1983) synthesis of brachiopod-dominated paleocommunities from the Welsh Basin. His study focused on a small geographic area dominated by siliciclastic sediments that was positioned at high paleo-latitudes during the Ordovician. North America, in contrast, was positioned at the equator and was the site of extensive carbonate platform development. A factor analysis of 165 North American assemblages was undertaken for comparison to Lockley's summary. The comparison suggests that the radiation of articulate brachiopods varied latitudinally, with different superfamilies radiating and achieving dominance in different biogeographic provinces. This pattern is also expressed by the relative abundance relationships among dominant genera making up the biofacies and therefore suggests that adaptation to local environmental parameters may have been an important governing factor.

The analysis of North American assemblages indicates that the composition of brachiopod biofacies changed dramatically as the Ordovician radiation unfolded. Ibexian and early Whiterockian shelf environments were dominated by orthaceans with porambonitaceans important in nearshore Ibexian environments. In the late Whiterockian a major turnover in biofacies composition occurred that marked the appearance and/or diversification of several new articulate superfamilies. Late Whiterockian through Cincinnatian offshore environments were characterized by plectambonitaceans and enteletaceans with strophomenaceans also moderately important. Nearshore environments were dominated by strophomenaceans, orthaceans, and rhynchonellaceans. Atrypaceans appeared nearshore in the Mohawkian but shifted their center of dominance offshore by the Cincinnatian. Deep basin environments were rarely inhabited by articulate brachiopods and were dominated throughout the Ordovician by inarticulates (lingulaceans). There was no major change in composition of the deep-water inarticulate biofacies that paralleled the turnover seen among articulates on the platforms.

The Welsh Basin biofacies described by Lockley are broadly similar to the North American biofacies. Orthaceans characterized Arenigian (late Ibexian and early Whiterockian) shelf environments. Orthaceans and strophomenaceans dominated Llanvirnian through Caradocian (early Whiterockian - early Cincinnatian) nearshore environments and plectambonitaceans and enteletaceans dominated offshore environments. Inarticulates were dominant in deep basin environments throughout the Ordovician. In contrast to North America, rhynchonellaceans and porambonitaceans, although present in the Welsh Basin, apparently never formed a distinct biofacies. In the case of the porambonitaceans, this may reflect poor sampling of Lower Ordovician strata. Enteletaceans, on the other hand, appeared earlier (Arenig) in the Welsh Basin than in North America and eventually diversified to become dominant in a broader range of environments that included the nearshore. 